\title{
Mortality from injuries and other causes in a cohort of 21800 Brazilian steel workers
}

\author{
S M Barreto, A J Swerdlow, P G Smith, C D Higgins, A Andrade
}

\begin{abstract}
Objectives-Injury is the leading cause of death in the male working population of Brazil. An important fraction of these deaths are work related. Very few cohort studies of steel workers, and none from developing countries, have reported on mortality from injuries. This paper analyses mortality from work and non-work related injuries among Brazilian steel workers.
\end{abstract}

Methods-Deaths during employment from 1 January 1977 to 30 November 1992 were analysed in a cohort of 21816 male steel workers. Mortality rates specific for age and calendar year among the workers were compared with those of the male population of the state where the plant is located. Work related injuries were analysed by comparing the mortality rates for different subgroups of the cohort.

Results-The number of deaths (391) was less than half that expected based on death rates of the general population. Over $60 \%$ (242) of deaths were due to injuries. Mortality from most causes was substantially below that in the general population, but that from unintentional injury, was $50 \%$ above that of the general population. Standardised mortality ratios (SMRs) were highest for the youngest and the oldest employees and for labourers and clerical workers. Mortality from motor vehicle injury was twice that expected from population rates $(\mathrm{SMR}=$ $209,95 \%$ confidence interval (95\% CI) 176-244). There was a $67 \%$ fall in the age adjusted mortality from occupational injuries in the study period.

Conclusion-The healthy worker effect in this cohort was greater than that commonly found in studies of occupational groups in developed countries, probably because of a greater socioeconomic gap between employed and unemployed populations in Brazil, and unequal distribution of health care resources. Mortality was especially high for motor vehicle injuries. The fall in mortality from occupational injuries during the study period was probably due to improvement in safety standards, increased automation, and better medical care. There is a need to investigate risk factors for unintentional injuries among steel workers, especially those due to motor vehicle injuries. Prevention of occupational and nonoccupational injuries should be a main priority in Brazil.

(Occup Environ Med 1996;53:343-350)

Keywords: cohort, mortality, injury

Injury is a major cause of death both in developed and developing countries. ${ }^{1}$ Unlike cancer, cardiovascular diseases, and other chronic diseases, injury disproportionately strikes the young, being the leading cause of loss of potential years of life for the male population in many countries (table 1). In the United Kingdom it is the commonest cause of death in people under the age of $30,{ }^{2}$ and in the United States injury is responsible for over $60 \%$ of all deaths in the age group 15-24 years and about $40 \%$ in the age group $25-44$ years. ${ }^{34}$

In Brazil, deaths from injury show a very similar pattern to those in the United States, being responsible for about $60 \%$ of deaths among men aged 15-44 years. ${ }^{5}$ Motor vehicle crashes were the greatest cause of potential years of life lost among the economically active male population of São Paulo in 1980-2.

Injuries related to work are thought to

Table 1 Percentage years of life lost in men under the age of 70 years for six major groups of causes of death in nine different countries, 1980 (numbers are percentages of total) ${ }^{52}$

\begin{tabular}{|c|c|c|c|c|c|c|c|}
\hline Country & Cancer & $\begin{array}{l}\text { Infectious or } \\
\text { parasitic }\end{array}$ & $\begin{array}{l}\text { Cerebro- } \\
\text { vascular } \\
\text { disorders }\end{array}$ & $\begin{array}{l}\text { Circulatory } \\
\text { diseases other } \\
\text { than } \\
\text { cerebrovascular }\end{array}$ & $\begin{array}{l}\text { Respiratory } \\
\text { diseases }\end{array}$ & $\begin{array}{l}\text { Injury or } \\
\text { poisoning }\end{array}$ & $\begin{array}{l}\text { Other or } \\
\text { unknown }\end{array}$ \\
\hline $\begin{array}{l}\text { Australia } \\
\text { Chile } \\
\text { Hong Kong } \\
\text { Hungary } \\
\text { Japan } \\
\text { Kuwait } \\
\text { Spain } \\
\text { Sweden } \\
\text { United States }\end{array}$ & $\begin{array}{r}16 \\
7 \\
23 \\
15 \\
21 \\
5 \\
16 \\
17 \\
13\end{array}$ & $\begin{array}{r}1 \\
9 \\
4 \\
1 \\
2 \\
13 \\
5 \\
1 \\
1\end{array}$ & $\begin{array}{r}3 \\
2 \\
5 \\
6 \\
10 \\
2 \\
2 \\
4 \\
4 \\
2\end{array}$ & $\begin{array}{r}20 \\
5 \\
7 \\
20 \\
11 \\
11 \\
14 \\
24 \\
19\end{array}$ & $\begin{array}{r}4 \\
10 \\
11 \\
6 \\
4 \\
10 \\
7 \\
3 \\
4\end{array}$ & $\begin{array}{l}32 \\
28 \\
21 \\
24 \\
28 \\
22 \\
21 \\
29 \\
35\end{array}$ & $\begin{array}{l}24 \\
39 \\
29 \\
28 \\
24 \\
37 \\
33 \\
22 \\
27\end{array}$ \\
\hline
\end{tabular}


account for a substantial fraction of deaths from injury, but figures are imprecise both because of underreporting and because the classification system used to assign causes of death does not enable deaths related to work to be identified readily. It is estimated that more than 12 workers die a day in Brazil as a result of injuries related to work. ${ }^{7}$ According to Ministry of Health data, there were over 640000 occupational accidents in 1991, of which about 4500 were fatal. During 1970-91 the number of workers covered by the National Insurance Institute tripled, but the number of occupational accidents reported halved, leading to a decline from 16.8 to $2 \cdot 8$ injuries per 100 employees. $^{7}$ This decline in injury rate probably reflects a real improvement in health and safety in many industrial sectors. It may also reflect the change in the composition of the workforce, with increased participation of low risk groups, such as women and those employed in services. A decline was not found for fatal injuries, which more than doubled during the same period, resulting in a sharp and highly significant upward trend in the case/fatality ratio (from 1.9 to 5.0 per 1000 injuries reported). The case/fatality ratio in recent years is much higher than that found in developed countries. For example, in Britain in 1990-1 the case/fatality ratio was 1.9 deaths per 1000 injuries. ${ }^{8}$ Underreporting of minor injuries might have contributed to both the decline in the overall accident rate and the increase in case/fatality ratio in Brazil, but this has not been investigated. ${ }^{9}$

There seem to have been no detailed cohort investigations of accident mortality in occupational groups in developing countries. Most occupational studies conducted in Brazil have either been cross sectional or of proportional mortality, mainly due to the lack of adequate follow up systems, and thus have had limitations for estimating risk and studying causal associations.

Most studies of the mortality of workers in the steel industry in developed countries have focused on cancer and respiratory diseases, ${ }^{10-17}$ and only a few have reported the risk of death from injuries. ${ }^{10121316}$ Most steel workers work on assembly lines, with a substantial proportion working in rotating shifts. There are several hazards in steel works which are associated with increased risk of injury such as heavy machinery, molten metal, gases, noise, and heat. ${ }^{18-22}$ Koskela et al found excess mortality from injuries (mainly suicide and transportation accidents) among casters, furnacemen, and fitters employed in iron foundries in Finland. ${ }^{13}$ In a study in the United States, Lloyd et al found an increased risk of death from accidents among labourers but the excess was not significant. ${ }^{10}$

The present study is of mortality from work and non-work related injuries in a cohort of steel workers employed in the manufacturing plant of USIMINAS, one of the largest producers of uncoated flat steel in the Americas. The plant is located in a region called the Steel Valley in the west of the state of Minas Gerais, in south east Brazil, where there is one of the largest iron ore reserves in the world-the ferrous quadrilateral of Minas Gerais. The steel works covers an area of $11 \mathrm{~km}^{2}$ and include 190 work areas, three large coke production units, and a by product recovery segment to collect and refine the volatile products of coal carbonisation.

\section{Materials and methods}

The cohort comprised all men employed at USIMINAS at any time between 1 January 1977 and 31 August 1990. Up to 1983, workers were identified from annual lists of those currently employed in the plant, held in personnel records. The sex, date of birth, place of birth, date of leaving the plant, and vital status on departure, were abstracted from microfiche records. From 1983 onwards employment data were available from computer files held in the personnel department.

Female workers were excluded from the study as they were few and worked mainly in clerical and administrative posts. Checks were made to eliminate duplicate records by comparing the names, dates of births, and work identity numbers for men in the cohort, with a computer program that took account of common spelling mistakes. Suspected duplicates were checked manually. Works numbers in the plant had been allocated sequentially by date of first employment, and these were used to check for temporal discrepancies in the data abstracted.

Information on deaths among cohort members during employment in the plant was obtained from personnel records, as date and cause of death are reported to the personnel department by the employee's family or next of kin to claim compensation or a pension from the National Institute of Social Security. Copies of the death certificates were obtained from the Occupational Health Department for all workers reported to have died and the causes of deaths were coded according to the 9th revision of the International Classification of Diseases (ICD-9). ${ }^{23}$

Workers in the cohort were regarded as entering the study on 1 January 1977 if they were already employed at that date, or on the date of employment if they started later. Follow up was ended on the earliest of the date of departure from the plant, death, or 30 November 1992. Years at risk were stratified according to age, in five-year age bands, two calendar periods (1977-84 and 1985-92), duration of employment (six groups) and five job categories (professionals, technicians, group leaders, clerical workers, and labourers) and deaths were similarly classified.

Mortality rates in the cohort were compared with the corresponding age and calendar year specific rates for the male population of Minas Gerais, the state in which the plant is located. The numerators for the Minas Gerais mortalities were abstracted from the Ministry of Health mortality files that contain data from death certificates for the whole country for the period 1979-89, classified according to 
Table 2 SMRs for different causes of death in the cohort

\begin{tabular}{|c|c|c|c|c|c|}
\hline ICD-9 code & Cause of death & Deaths observed $n$ & Expected $n$ & $S M R$ & $(95 \% C I)$ \\
\hline $\begin{array}{l}000-139 \\
140-208 \\
390-459 \\
460-519 \\
520-579 \\
000-797 \\
000-797 \\
798-799 \\
\text { E800-E949 } \\
\text { E950-E969 } \\
\text { E980-E989 } \\
\text { E800-E999 } \\
000-999\end{array}$ & $\begin{array}{l}\text { Infectious and parasitic } \\
\text { Malignant neoplasms } \\
\text { Cardiovascular } \\
\text { Respiratory system } \\
\text { Digestive system } \\
\text { Other natural causes } \\
\text { All natural causes } \\
\text { Unknown and ill defined } \\
\text { All unintentional injuries } \\
\text { Intentional injuries } \\
\text { Unclassified injuries* } \\
\text { All injuries } \\
\text { All causes }\end{array}$ & $\begin{array}{r}11 \\
41 \\
53 \\
7 \\
11 \\
20 \\
143 \\
6 \\
192 \\
40 \\
10 \\
242 \\
391\end{array}$ & $\begin{array}{r}55 \cdot 4 \\
44 \cdot 2 \\
160 \cdot 4 \\
30 \cdot 8 \\
57 \cdot 8 \\
59 \cdot 1 \\
418 \cdot 0 \\
149 \cdot 0 \\
127 \cdot 9 \\
65 \cdot 4 \\
58 \cdot 5 \\
251 \cdot 8 \\
818 \cdot 8\end{array}$ & $\begin{array}{r}20 \\
93 \\
33 \\
23 \\
19 \\
34 \\
34 \\
4 \\
150 \\
61 \\
17 \\
96 \\
48\end{array}$ & $\begin{array}{l}(10-34) \\
(67-124) \\
(25-43) \\
(10-33) \\
(10-33) \\
(21-51) \\
(29-40) \\
(2-8) \\
(130-172) \\
(44-82) \\
(9-30) \\
(85-109) \\
(43-53)\end{array}$ \\
\hline
\end{tabular}

${ }^{\star}$ Not classified whether accidentally or purposely inflicted.

ICD-9. The denominators were obtained from census data and between census population estimates (FIBGE-Fundacao Instituto Brasileiro de Geografia e Estatistica).

Minas Gerais mortalities were calculated for single years from 1979-89. Rates for 1977 and 1978, which were not available, were taken to be the same as those for 1979 , and those for 1990-92 were taken to be the same as those for 1989. Expected numbers of deaths were obtained by multiplying specific mortality rates for age and calendar year for the Minas Gerais population by the corresponding number of person-years in the study population. Standardised mortality ratios (SMRs) were calculated by incorporating external rates into Poisson regression models with EPICURE software. ${ }^{24}$ Significance levels and confidence intervals (CIs) were calculated assuming that the specific rates for age and calendar year in the cohort were a constant multiple of those in the general population. ${ }^{25}$

The ICD-9 makes no provision for recording whether injuries are related to work. A death was therefore ascertained as related to work injury if the underlying cause on the death certificate was injury and the Occupational Health and Industrial Hygiene Departments had notified it to the Brazilian Health and Safety Authorities as occupational. The industry is obliged by law to keep records of, and to notify Health and Safety Authorities of, all fatal and non-fatal occupational injuries as soon as they occur.

Deaths from these causes in the cohort were analysed by comparison of the mortality rates of different groups of workers in the cohort.

EPICURE computer software was also used

Table 3 SMRs for all causes of death according to duration of employment and job category

\begin{tabular}{|c|c|c|c|c|}
\hline \multirow[b]{2}{*}{ Fob category } & \multirow{2}{*}{$\begin{array}{l}\text { Duration of } \\
\text { employment }(y)\end{array}$} & \multicolumn{2}{|l|}{ Deaths } & \multirow[b]{2}{*}{$\operatorname{SMR}(95 \% C I)$} \\
\hline & & Observed $n$ & Expected $n$ & \\
\hline - & $<1$ & 15 & $24 \cdot 4$ & $61(35-98)$ \\
\hline - & $1-2$ & 18 & $28 \cdot 8$ & $62(38-96)$ \\
\hline - & $3-4$ & 78 & $104 \cdot 9$ & $74(59-92)$ \\
\hline - & $5-9$ & 94 & 183.8 & $51(41-62)$ \\
\hline - & $10-19$ & 147 & $357 \cdot 5$ & $41(35-48)$ \\
\hline \multirow[t]{2}{*}{ - } & $\geqslant 20$ & 39 & $119 \cdot 3$ & $33(24-44)$ \\
\hline & \multicolumn{3}{|c|}{$\chi^{2}$ trend $(1 \mathrm{df})=19.7, \mathrm{P}<0.0001$} & \\
\hline Professionals & - & 17 & $53 \cdot 3$ & $32(19-50)$ \\
\hline Technicians & - & 62 & $180 \cdot 7$ & $34(27-44)$ \\
\hline Group leaders* & - & 34 & $121 \cdot 6$ & $28(20-39)$ \\
\hline Labourers & - & 237 & $394 \cdot 2$ & $60(53-68)$ \\
\hline \multirow{2}{*}{ Clerical workers } & - & 41 & $69 \cdot 0$ & $59(43-79)$ \\
\hline & \multicolumn{3}{|c|}{$\chi^{2}$ heterogeneity $(4 \mathrm{df})=36.0, P<0.001$} & \\
\hline
\end{tabular}

^Skilled manual workers who supervise the work of a group of labourers. to fit log linear models to estimate exposure specific rate ratios and to test hypotheses relating to them..$^{24}$ Adjustments for age and calendar period were made by including terms for these factors in the model. A maximum likelihood test was used to test for possible interaction effects with age group and calendar period.

\section{Results}

A total of 22355 people were employed in the steel works at any time from 1 January 1977 to 31 August 1990, of whom 441 were women and were excluded. Microfiches containing personnel data for $98(0.04 \%)$ of the 21914 male steel workers were missing and these workers were also excluded. Thus, the final cohort consisted of 21816 male steel workers who contributed 197499 person-years of follow up. Forty nine per cent of the men (10 679) were still working in the plant at the end of the study period, $49 \%$ (10 746) had left employment (dismissed, retired, or resigned), and $2 \%$ (391) had died during employment. The mean (SD) duration of employment was $11: 9(7 \cdot 8)$ years and the duration of follow up was $9 \cdot 0(5 \cdot 8)$. The age range of the cohort was 17 to 65 years. Most steel workers (75\%) were first employed before 25 years of age, the mean (SD) age being $22 \cdot 8$ years (4.9). The mean age of those still working at the plant at the end of the study period was $36 \cdot 4(4 \cdot 0)$ years.

Of the 391 deaths that occurred during employment, $242(62 \%)$ were caused by injury (table 2), 53 (14\%) by cardiovascular diseases, and $41(10 \%)$ by malignant neoplasms. The expected total number of deaths, based on Minas Gerais rates, was 818.8 (SMR 48 , table 2). The SMRs were low for all major causes of death except malignant neoplasms, for which the mortality approached that of the general population, and unintentional injuries, for which mortality was above that of the general population. The SMR for death from unknown and ill defined causes (ICD-9 798-799) was very low, indicating a much greater accuracy in ascertainment of causes of death for the cohort than for the population of Minas Gerais (table 2).

The SMRs for all causes of death combined declined with increasing duration of employment in the steel works (table 3). Age was stratified into four groups of 10 -year intervals 
Table 4 Deaths from injury according to underlying cause on death certificate

\begin{tabular}{llcc}
\hline ICD-9 code & Cause of death & $\begin{array}{l}\text { Total } \\
n(\%)\end{array}$ & $\begin{array}{c}\text { Work related } \\
n(\%)\end{array}$ \\
\hline Unintentional injuries: & Motor vehicle injury & $192(79 \cdot 3)$ & $33(89 \cdot 2)$ \\
E810-E825 & $146(60 \cdot 3)$ & $9(24 \cdot 3)$ \\
E888 & Fall & $1(0 \cdot 4)$ & $1(2 \cdot 7)$ \\
E899 & Burning & $11(4 \cdot 5)$ & $11(29 \cdot 7)$ \\
E910 & Drowning & $20(8 \cdot 3)$ & $0(0)$ \\
E919 & Injury caused by machine & $5(2 \cdot 1)$ & $5(13 \cdot 5)$ \\
E925 & (not specified) & $2(0 \cdot 8)$ & $2(5 \cdot 4)$ \\
E928 & Electrocution & $5(13 \cdot 5)$ \\
Intentional injuries: & Other unintentional injury & $6(2 \cdot 5)$ & $0(0)$ \\
E953-E958 & Suicide & $40(16 \cdot 5)$ & $0(0)$ \\
E965-E968 & Homicide & $13(5 \cdot 4)$ & $0(0)$ \\
Injuries not classified whether & & $27(11 \cdot 1)$ & \\
accidental or & & $10(4 \cdot 2)$ & $4(10 \cdot 8)$ \\
purposely inflicted: & Poisoning by gases or vapours & $4(1 \cdot 7)$ & $4(10 \cdot 8)$ \\
E982 & Other injuries and those with & $6(2 \cdot 1)$ & $0(16 \cdot 2)$ \\
E988 & means not specified & $242(100)$ & $37(100)$ \\
E800-E999 & All external causes & & \\
\hline
\end{tabular}

to test for a possible interaction effect with duration of employment, and calendar period was stratified into two periods (1977-84 and 1985-92). There was no significant interaction on a multiplicative scale, between age and duration of employment $(P=0 \cdot 26)$, or between duration of employment and calendar period $(P=0.34)$.

All cause mortality was significantly below that of the general population for workers in all five job categories examined (table 3 ). The SMRs varied significantly $(P<0.001)$ according to job category, being greater for labourers and clerical workers than for the other three job categories. The SMRs by job category did not vary significantly by age $(P=0.22)$ or calendar period $(P=0 \cdot 10)$.

Table 4 shows the distribution of causes of

Table 5 Mortalities for deaths from motor vehicle injury (compared with general population)

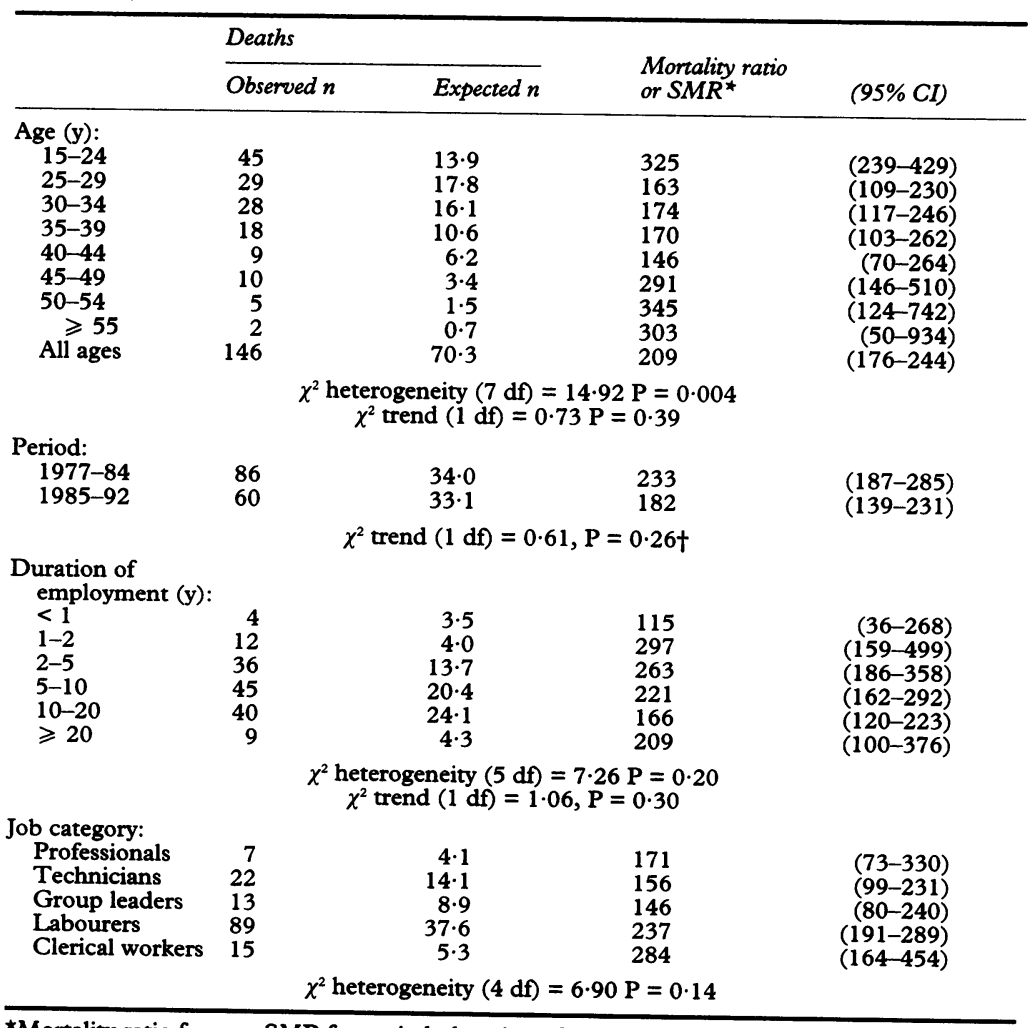
^Mortality ratio for age; SMR for period, duration of employment, and job category.
+ Trend test based on single years. death from injury. Motor vehicle accidents, which include pedestrian injuries, accounted for $37 \%$ of all deaths and $60 \%$ of all injury deaths. Suicide and homicide accounted for $16 \%$ of injury deaths and drowning for $8 \%$. Thirty seven deaths were related to work (table 4). Injuries related to work were responsible for about $10 \%$ of all deaths, and $15 \%$ of all fatal injuries. Burns were the most common cause of occupational injury, with 11 deaths (table 4); two of these occurred on the same date, probably as a result of the same accident. The numbers of deaths related to work were greatest in 1978 (eight deaths) and 1979 (nine deaths) and there were no occupational fatalities in 1989 and 1990

Mortality rates for motor vehicle injury were significantly above those of the general population of Minas Gerais, most notably so for workers aged $<25$ years or $>44$ years (table 5). The SMR for motor vehicle injuries was higher in 1977-84 than in 1985-92, but the difference was not significant and there was no evidence of a significant trend in the SMRs analysed in single years.

The SMRs for motor vehicle injuries were significantly increased for workers who had been employed for $>$ one year in the plant but did not vary greatly with duration of employment beyond this (table 5). There was an excess of deaths from motor vehicle injury in each job category. Risks were generally greatest for the two least skilled groups, but the variation in the SMRs between groups was not significant.

Seventy three per cent (27) of the deaths classified as work related occurred among workers aged less than 35 years (table 6). The death rates from these causes were greatest among those aged $<25$ years or $>45$ years, but the variation in the rate ratios with age was not significant.

There was a $67 \%$ decline in the age adjusted mortality rates from injuries related to work in 1985-92 compared with 1977-84, and the trend in the age adjusted rate ratios by single calendar year was highly significant (table 6: $P=0.002$ ). The mortality for injuries related to work was greatest for workers during their first year of employment, but did not vary significantly thereafter (table 6). There was significant variation in risk of fatal injury related to work by job category (table $6)$. No death from this cause occurred among clerical workers and only one death occurred among professionals.

In table 7 age specific mortality rates for motor vehicle injury in the cohort are compared with specific mortalities for sex and age for Brazil, and for England and Wales as a comparison from a developed country. Data for all unintentional injuries are also shown for the cohort for England and Wales, but were not available in comparable form for Brazil. For most age groups rates of motor vehicle injury in the cohort are about twice those for Brazil and several times those for England and Wales. For all unintentional injuries rates in the cohort were several times those in England and Wales in most age groups. 
Table 6 Mortality rates and rate ratios for work related injuries

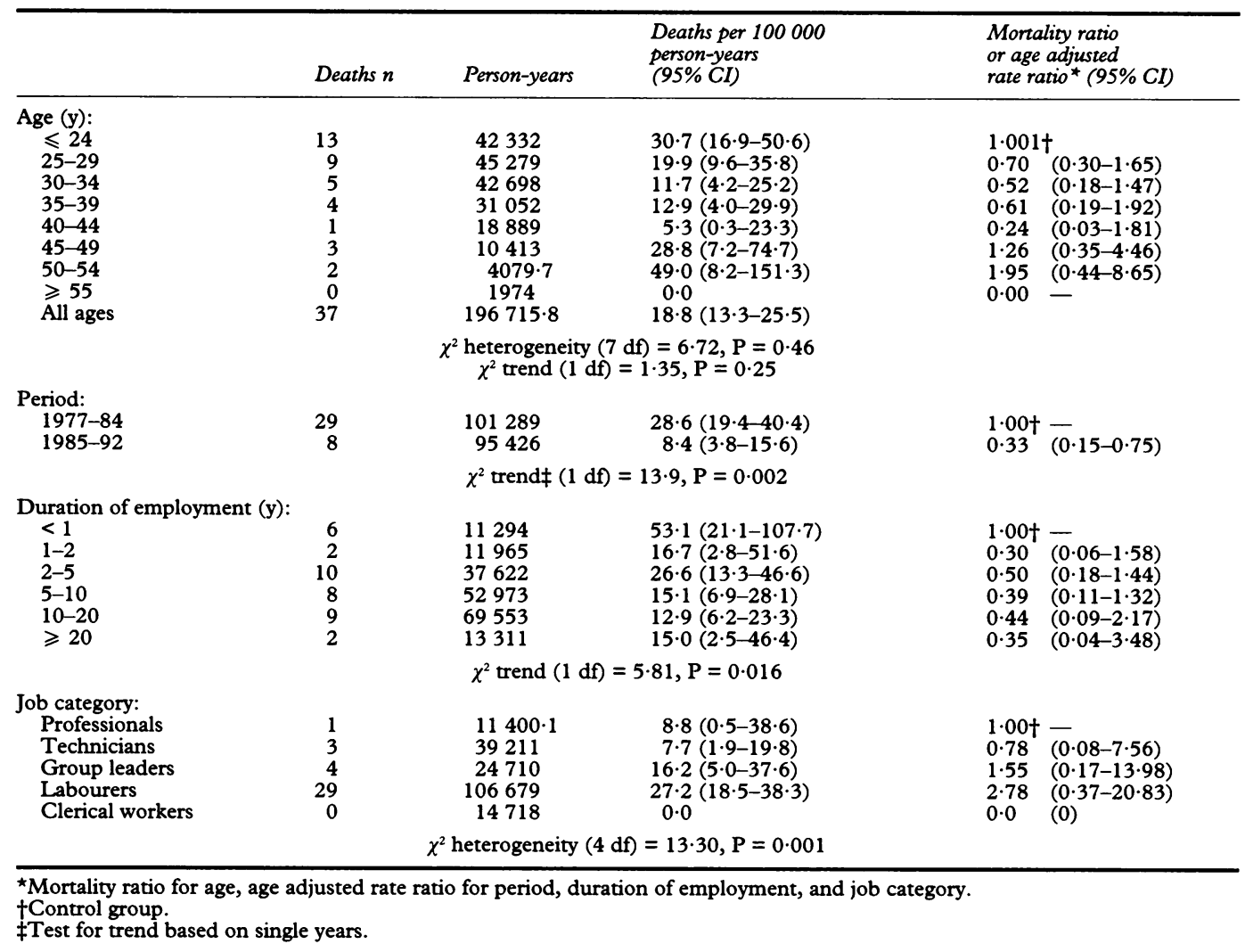

Table 7 Age specific annual mortalities (per million) from motor vehicle and all unintentional injuries in the cohort, Brazil, and England and Wales

\begin{tabular}{lrll}
\hline Age group & Cohort & Brazil $^{\star}$ & England and Walest \\
\hline Motor vehicle injuries: & & & \\
$15-19$ & 423 & 206 & 315 \\
$20-29$ & 882 & 411 & 228 \\
$30-39$ & 1051 & 457 & 112 \\
$40-49$ & 648 & 460 & 96 \\
$50-64$ & 1165 & $-\ddagger$ & 107 \\
All unintentional injuries: & 1512 & - & 399 \\
$15-24$ & 887 & - & 269 \\
$25-34$ & 587 & - & 427 \\
$35-44$ & 1264 & - & 227 \\
$45-54$ & 1520 & & 395 \\
$55-64$ & & & \\
\hline
\end{tabular}

*Based on rates for the male population of Brazil, for the years 1979, 1983, and 1987. †Based on rates for the male population of England and Wales from 1979 to 1992 (OPCS). $\neq$ Data not available in this form for Brazil. found to be sick may change their job, leave employment, or be treated at an early stage of disease.

Among the steel workers, the SMRs for all causes of death were lowest for those who had been employed longest (table 3 ). In part this was because of greater accident mortality in less experienced workers, ${ }^{34}$ but also workers who are more healthy are likely to stay working longer. In other studies it has been found that men who had experienced unemployment or retired prematurely had higher death rates than continuously employed men, ${ }^{31}$ and among Finnish foundry workers poor health was one of the four main reasons for leaving employment. ${ }^{32}$ In Brazil there have been fewer job opportunities than in developed countries and an unsatisfactory welfare system to assist those out of work. As a consequence, the differences in mortalities between employed and unemployed men are likely to be even more pronounced than in developed countries. In our cohort the all cause SMR, and especially the all "natural" cause SMR, was much lower than usually found in working cohorts in developed countries. ${ }^{10-17}$

There may be differences between the study population and the state population in both the completeness of ascertainment of deaths and of their causes, as is indicated by the very low SMR for unknown and ill defined causes in the study population (table 2) and this may limit the interpretation of our findings. As the personnel records are used to pay workers, incomplete ascertainment of death is unlikely, and reports by the Ministry of Health indicate that there is little underreporting of deaths in the general population among people of working age. ${ }^{35}$ The very low SMR for ill defined 
causes (table 2), however, indicates a substantial difference in the accuracy of determining cause of death. This occurs particularly because in Brazil non-working populations have little access to medical services although workers employed in large companies such as USIMINAS, are generally covered by special health insurance plans. Differences in accuracy in determining causes of death are less likely to affect deaths from injuries than those from other causes that require medical or laboratory investigations. It is likely that within the general population a high proportion of deaths classified as due to unknown or ill defined causes were due to natural causes, ${ }^{36}$ and thus the SMRs from these causes in the cohort (table 2) are likely to be overestimated.

The low SMR for injuries not known whether accidentally or purposely inflicted (table 2) contrasts with the SMR of 150 for unintentional injuries and suggests differences between this cohort and the general population for accuracy in the establishment of cause of death from injury. It is often difficult to establish that injury deaths are purposely inflicted $^{37-41}$ as this conclusion generally requires both legal and medical investigations. An appreciable proportion of the difference in accuracy between the cohort and general population data may therefore have been due to better ascertainment of deaths from intentional injuries in the cohort compared with the general population. The excess of deaths from unintentional injuries in the cohort is also appreciably larger than the deficit of ill specified injuries and thus the excess of deaths found in comparison with general population rates is likely to be largely real. It may well reflect an even larger excess of serious injuries, as employees of USIMINAS have benefited from better access to medical care than has much of the population, and promptness and quality of medical care are associated with increased survival and low mortality from injuries. ${ }^{1442} 43$

Mortality from motor vehicle injuries was twice as high in USIMINAS workers as in the general population (table 5). The risk of such injuries is highly influenced by driver and pedestrian behaviour. Factors such as the nonuse of seat belts and helmets (for motor cyclists), drinking alcohol, and speeding are among the most important risk factors for traffic accidents. Although there are strict rules about the use of helmets in the state of Minas Gerais, there has been great concern about high speed riding and traffic offences among motor cycle riders. Motor cycles are very popular among steel workers because they cost less than cars and can negotiate heavy traffic more easily. The ownership of motor cycles may be more common among workers in the steel works than in the general population. Unfortunately it is not possible to ascertain from the death certificates whether deaths were due to motor cycle or car accidents.

During the study period the use of seat belts was only legally compulsory on motorways and main roads in Brazil. Tighter regulation of alcohol consumption by drivers has been imposed only recently, and would not have affected cohort mortality. However, we know of no reason why steel workers should have behaved worse than the general population in the use of seat belts, helmets, or other preventive measures.

There might be some differences in drinking habits between the cohort and the general population, but there are no data on alcohol consumption to compare the two populations. A cross sectional study in Brazil found a significantly lower prevalence of alcohol consumption and alcoholism among people earning three or less times the minimum wage than among those earning four or more times. ${ }^{44}$ Although an important proportion of steel workers have low pay, the general population includes an even greater proportion of people in this situation.

Regional variations in mortality from traffic injuries might explain some differences between cohort and population rates if mortality was higher in the Steel Valley than in the state as a whole. In studies elsewhere than Brazil, death rates from traffic injuries have varied inversely with the per capita income, ${ }^{44346}$ probably because in low income areas the percentage of paved roads is lower, vehicles are older and less well maintained, driving practices are less safe, and efficient emergency and medical care services are lacking. Nationally, however, there is no clear pattern of variation in traffic mortality between low and high income regions. ${ }^{45}$ In the state of Minas Gerais there is a notable regional variation in degree of urbanisation and wealth, but there is little information on regional variation in mortalities from road injuries. The Steel Valley is highly urbanised and one of the most prosperous areas.

The increasing risk of death from motor vehicle injury after the first year of employment (table 5) may be explained by several factors. Amount of travel is positively associated with the risk of traffic accidents and explains some of the differences in mortality for this cause when international comparisons are made. ${ }^{47} \mathrm{~A}$ person's amount of travel may increase with duration of employment. Employment may lead to financial betterment and increased ownership of cars and other motor vehicles. As a consequence the chances of traffic accidents may also rise after employment. However, there is no obvious reason for a relation between dangerous driving and duration of employment. Alcohol misuse might lead to an increase in the risk of death from motor vehicle injuries with increasing duration of employment. There is some evidence of an increase in alcohol consumption among young adults after employment has begun. ${ }^{48}$ Such an increase may occur not only because drinking becomes more affordable but because of an increase in the intensity of social life and of stress from work. A person's drinking behaviour seems to be strongly influenced by the drinking habits of those in his personal social network. ${ }^{49}$

Some related to work factors, such as rotating shift work, might also contribute to the 
increased risk of deaths from motor vehicle injury among steel workers. More than $40 \%$ of the steel workers are currently exposed to levels of noise of 85 decibels and above, and there is a high prevalence of noise induced hearing loss. Another major health problem in the steel works is mental illness, which is an important cause of absenteeism and early retirement. ${ }^{50}$ These factors might be associated with increased risk of traffic injury because they can cause reduction in alertness and concentration, and delay in reaction time.

The decline in mortality from injuries related to work over time may be explained by improvement in safety standards in the plant, technological progress, with machines taking over some of the more hazardous tasks, and better medical care. During the study period, the Departments of Occupational Health and Industrial Hygiene carried out many campaigns and introduced measures with the intention of reducing accidents at work, which seem to have had an important impact on accident prevention. These campaigns were based on promoting training courses, increasing awareness of hazards and importance of safety measures, and also rewarding, with a barbecue or a party, workers in areas where no accidents occurred. At the same time the presence and support of industrial hygienists in the production areas has increased.

The crude mortality for occupational injury in south east Brazil was around 7.8 per 100000 employees in $1990,{ }^{7}$ similar to that found in this cohort towards the end of the study period (table 6). Unfortunately, other cohort studies of steel workers have not published comparable data on mortality from occupational injuries. ${ }^{10-16}$ In developed countries the occupational mortality may be much less. For example, for workers in manufacturing in Britain, the rate was 1.8 per 100000 employees in $1990-1,{ }^{4}$ nearly one fifth of that found in this cohort. However these crude rates include both sexes and several occupations, and there may also be differences in age composition. Death rates for occupational injury vary greatly according to sex, age, and occupation. ${ }^{4851}$ Also, comparisons of mortalities for occupational injuries are subject to important bias because of variation in case definition and methods of data collection between and even within countries. In the United States, for instance, the estimated numbers of fatal occupational injuries vary widely (3740 to 11500 in 1984) among the various surveillance systems. ${ }^{4}$ Although Brazilian health and safety statistics include occupational fatalities and injuries related to motor vehicles in people under the age of 16 years, the National Traumatic Occupational Fatality Database in the United States does not. In Brazil data on occupational injuries are not available for 14 million rural workers. ${ }^{9}$

In conclusion, the analyses of mortality in this cohort show a substantially higher risk of death from injury than in developed countries and a greater healthy worker effect. In comparison with the state population there was a highly significant excess of death from unin- tentional injury in the study population, in particular from motor vehicle injuries. There is a clear need for preventive action and further exploration of possible risk factors for death from injury among Brazilian steel workers.

An increase in knowledge of occupational hazards and the efficacy of preventive methods available in Brazil should help to enhance effective interventions, increase enforcement of safety legislation, and further the use of engineering approaches to reduce hazards in the workplace and their adverse consequences on the morbidity and mortality of those affected.

The study was only possible because of the full and willing cooperation of the occupational health department of USIMI NAS in Brazil and the help of many others from personnel and the industrial hygiene departments. José Ronaldo de Almeid and Carlos AMP Filho coordinated the data collection. We are grateful to Drs David Leon, Tony Fletcher, and Michael Hills for advice and to Evelyn Middleton for secretarial help. The International Agency for Research on Cancer (IARC/W/HO) International Agency for Research on Cancer (IARC/WHO) provided financial and scientific support in the initial stage of the study, and the International Development Research Centre IDRC) funded the main study. The study formed part of SB' $\mathrm{PhD}$ thesis (University of London, 1995) supported by the Brazilian Research Council (CNPQ). The Epidemiological Monitoring Unit is supported by a grant from the Medical Research Council.

1 Langley JD. The role of surveillance in reducing morbidity and mortality from injuries. Morbidity and Mortality Weekly Report 1992;41 (suppl):181-90.

2 Department of Health. Accidents by area handbook 1993. London: HMSO, 1993.

3 Robertson LS. Injury epidemiology. Oxford: Oxford University Press, 1992

4 National Committee for Injury Prevention and Control (US). Injury prevention: meeting the challenge. New York: Oxford University Press, 1989

5 PAHO (Pan American Health Organization). Mortality: trends from 1960 to 1990 and latest data by cause, age, and sex. PAHO, 1992:19-27.

6 Rumel D. Indicadores de mortalidade por categoria profissional $e$ nivel social-Estado de São Paulo, 1980-2. 1987. University of São Paulo. (Unpublished MSc dissertation.)

7 Alves S, Luchesi G. Acidentes de trabalho e doencas profissionais no Brasil-a precariedade das informações. Informe epidemiologico do SUS 1992;3:7-19.

8 Mayatt VL. Accidents in industry. $尹 R$ Soc Health 1992 12:297-300

9 Ribeiro HP. Os acidentes de trabalho estão caindo: sonegação ou realidade? SOS Revista Associaçáo Brasileira para Prevençáo de Acidentes 1993;5:14-21.

10 Lloyd JW, Lundin FE, Redmond CK, Geiser PB. Longterm mortality study of steelworkers-Mortality by work area. F Occup Med 1970;12:151-8.

11 Blair A. Mortality among workers in the metal polishing and plating industry, 1951-69. F Occup Med 1980;22: $158-62$.

12 Decoufle $\mathrm{P}$, Wood $\mathrm{D}$. Mortality patterns among workers in a grey iron foundry. Am $\mathcal{f}$ Epidemiol 1979;109:667-75.

13 Koskela RS, Hernberb S, Karava R, Jarvinen E, Nurminen M. A mortality study of foundry workers. Scand $\mathcal{F}$ Work M. A mortality study of foundr

14 Tola S, Koskela RS, Hernberb S, Jarvinen E. Lung cancer mortality among iron foundry workers. $f$ Occup Med 1994;21:753-60.

15 Fletcher AC, Ades A. Lung cancer mortality in a cohort of English foundry workers. Scand $\mathcal{F}$ Work Environ Health 1984;10:7-16

16 Egan-Baum E, Miller BA, Waxweiler RJ. Lung cancer and other mortality patterns among foundry men. Scand Work Environ Health 1981;7:147-55.

17 Sorahan T, Cooke MA. Cancer mortality in a cohort of United Kingdom steel foundry workers:1946-85. $\mathrm{Br} \mathcal{F}$ Ind Med 1989;46:74-81.

18 Suruda AJ. Work-related deaths in construction painting Scand $\mathcal{F}$ Work Environ Health 1992;18:30-3.

19 Moll van Charante AW, Mulder PGH. Perceptual acuity and the risk of industrial accidents. Am $f$ Epidemiol $1990 ; 131: 652-63$

20 Dukes-Dobos FN. Hazards of heat exposure. Scand $\mathcal{f}$ Work Environ Health 1981;7:73-83.

21 Seppalainen AM. Neurophysiological findings among workers exposed to organic solvents. Scand $f$ Wor Environ Health 1981;7(suppl 4):29-33.

22 Juntunen J, Ylikoski J, Ojala M, Matikainen E, Ylikoski M, Vaheri E. Postural body sway and exposure to highenergy impulse noise. Lancet 1987;ii:261-4.

23 World Health Organisation. Manual of the international clas sification of diseases, injuries, and causes of deaths, 9th revision. Geneva: WHO, 1977.

24 EPICURE. Siatto, WA: Hirosoft International Corporation. 1990 . 
25 Breslow NE, Day NE. Statistical methods in cancer research. Vol 2. The analysis of cohort studies. Lyon: International Agency for Research on Cancer (IARC-WHO), 1987. (Sci Publ No 32.)

26 Carpenter L. Some observations on the healthy worker effect. Br $\mathcal{F}$ Ind Med 1987;44:289-91.

27 Wang J, Miettinen OS. Occupational mortality studies: principles of validity. Scand $\mathcal{F}$ Work Environ Health 1982; principles

28 Monson RR. Observations on the healthy worker effect. $\mathcal{F}$ Occup Med 1986;28:425-33.

29 Fox AJ, Collier PF. Low mortality rates in industrial cohor studies due to selection for work and survival in the industry. Br F Prev Soc Med 1976;30:225-30.

30 Gardner MJ. Considerations in the choice of expected numbers for appropriate comparisons in occupationa cohort studies. Med Lav 1986;77:23-47.

31 Morris JK, Cook DG, Shaper AG. Loss of employment and mortality. $B M 7$ 1994;308:1135-9.

32 Koskela RS, Luoma K, Hernberb S. Turnover and health selection among foundry workers. Scand $\mathcal{f}$ Work Environ Health 1976;2(suppl 1):90-105.

33 Carpenter L, Beral V, Fraser P, Booth M. Health related selection and death rates in the United Kingdom Atomic selection and death rates in the United Kingdom Atomic Energy

34 Browne RC. Health in industry. London: Edward Arnold, 1961

35 Becker RA. Análise de Mortalidade-delineamentos básicos. Brasilia: Ministerio da Saúde. Fundação Nacional de Saúde. Coodenação de Informações Epidemiologicas. 1991

36 Armstrong DL, Wing SB, Tyroler HA. United States mortality from ill-defined causes, 1968-88: Potential effects on heart disease mortality trends. Int 7 Epidemiol 1995 24:522-7.

37 Diekstra RFW, Gulbinat W. The epidemiology of suicidal behaviour: a review of three continents. World Health Statistics Quarterly 1993;46:52-68.

38 Hammett M, Powell KE, O'Carroll PW, Clanton ST Homicide surveillance-United States, 1979-88. Homicide surveillance-United States, 1979-88.
Morbidity and Mortality Weekly Report 1992;41 (suppl 3):25.

39 Onwuachi-Sauders C, Hawkins DF. Black-white differ- ences in injury: race or social class. Ann Epidemiol 1993; 3:150-3.

40 Romano PS, McLoughlin E. Unspecified injuries on death certificates: a source of bias in injury research. $A m \mathcal{F}$ Epidemiol 1992;136:863-72.

41 Mello Jorge MHP. Situacao atual das estatisticas oficiais relativas a mortalidade por causas externas. Rev Saude Publ 1990;24:217-23.

42 Fleming NS, Becker ER. The impact of the Texas 1989 motorcycle helmet law on total and head-related fatalimotorcycle helmet law on total and head-related fatalities, severe

43 Van Beeck EF, Mackenbach JP, Looman CWN, Kunst AE. Determinants of traffic accident mortality in the Netherlands: a geographical analysis. Int $\mathcal{f}$ Epidemiol 1991;20:698-706.

44 Almeida LM, Coutinho ESF. Prevalencia de consumo de bebidas alcoolicas e de alcoolismo em uma regiao metropolitana do Brasil. Rev Saude Publica 1993;27:23-9.

45 Mello Jorge MHP, Latore MRDO. Acidentes de transito no Brasil: dados e Tendencias. Cad Saude Publ 1994;1: 19-44.

46 Lowenfels AB, Wynn PS. One less for the roadInternational trends in alcohol consumption and vehicular fatalities. Ann Epidemiol 1992;2:249-56.

47 Johnston I Action to reduce road casualties. World Health Forum 1992;13:154-62.

48 Temple MT, Fillmore KM, Hartka E, Johnstone BM Leino EV, Motoyoshi MM. A meta-analysis of change in marital and employment status as predictors of alcohol consumption on a typical occasion. British fournal of Addiction 1991;86:1269-81.

49 Duffy JC. The distribution of alcohol consumption 30 years on. British fournal of Addiction 1986;81:735-41.

50 Andrade A, Souza ME, Pedrosa TMG. $A$ aposentadoria por invalidez na Usina Intendente Camara. Monograph Faculdade de Medicina de Minas Gerais. Belo Horizonte: UFMG. 1990.

51 Baker SP, Samkoff JS, Fisher RS, Van Buren CB. Fatal occupational injuries. $\mathscr{f} A M A$ 1982;248:692-7

52 Tomatis L, Aitio A, Day NE, Heseltine E, Kaldor J, Miller $\mathrm{AB}$, et al. Cancer: causes, occurrence and control. Lyon: AB, et al. Cancer: causes, occurrence and control. Lyon: (IARC Sci Publ No 100.) 